\title{
THE PERCEPTION OF SOCIETY ON JUDICIAL CANING AS THE IMPLEMENTATION OF QANUN JINAYAH (PSYCHOLOGICAL PERSPECTIVE)
}

\author{
Nurbaiti* \\ Department of Psychology, Syiah Kuala University, Indonesia \\ nurbaitibetty5@gmail.com \\ Haiyun Nisa \\ Department of Psychology, Syiah Kuala University, Indonesia \\ haiyunnisa@unsyiah.ac.id
}

\begin{abstract}
The implementation of a rule and form of punishment to create a safe and prosperous society will have an effect and impact on the fabric of society life. The implementation of judicial caning stipulated in the Qanun Jinayah has gained diverse views from the society. The purpose of this study was to determine how society's perceptions of the implementation on judicial caning. This study used a qualitative method with observation and focus group techniques. A total of 31 people from 3 (three) regions in Banda Aceh City were selected as research respondents using purposive sampling techniques. The results point out that the perceptions that arise from the society are influenced by knowledge and views on judicial caning and its implementation as well as the psychosocial conditions of the society. The society does not quite understand the nature of Jinayah law, the purpose of punishment, and the order as well as the law to be realized. On the other hand, the society also considers that judicial caning can provide a deterrent effect and learning to the society so that it does not violate on the Sharia law.
\end{abstract}

Keywords: Caning, Perception, Qanun Jinayah, Society

${ }^{*}$ Corresponding Author 


\section{INTRODUCTION}

The society of Aceh is known as religious communities which make Islamic Sharia as the basis and standard for managing life in the various aspects. All dimensions of society life are regulated by Islamic Sharia law, it is due to the implementation of religious life which is realized in the form of Islamic Sharia is carried out in a kaffah or comprehensively (Abbas, 2011).

The Law on Aceh Government requires regional regulations or Qanun in the context of implementing Islamic Sharia (Dinas Syariat Islam Aceh, 2015). Qanun according to statutory regulations is a kind of Regional Regulation (Perda) which regulates the administration of government and the society life of Aceh (Pemerintahan Aceh, 2014). One of the Qanun fields is related to the administration of the society life in Aceh includes Sharia legal material or criminal law that was equipped in Aceh Qanun Number 6 of 2014 concerning Jinayat Law (Ulya, 2016).

Aceh Qanun Number 6 Year 2014 regulates the perpetrators of violations of Islamic Sharia, acts or forms of violations of Islamic Sharia (jarimah), and the threats that can be imposed on the perpetrators of Jarimah ('uqubat). Jarimah includes adultery, qadzaf, rape, sexual harassment, khamar, maisir, khalwat, ikhtilath, liwath, and musahaqah (Dinas Syariat Islam Aceh, 2015). Mahdi (2011) added that the form of punishment for the perpetrators of jarimah is imprisonment, fines and or judicial caning.

The implementation of the Qanun Jinayah raises the pros and cons in various circles both academics, practitioners and ordinary people especially related to the process of implementing judicial caning given to the violators of Islamic Sharia. These problems have not only arisen in the regions, but also at the national and even international level. As the refusal of the Institute for Criminal Justice Reform (ICJR), an institution that firmly creates resistance with many writings contained in online media.

The ICJR urges the Government of Indonesia to immediately take evaluative steps to eliminate all forms of corporate criminality in its laws and regulations, and declare that juridical caning is proven to be useless (Institute for Criminal Justice Reform, 2017).

Reports on the controversy of judicial caning in Aceh were also published in Voice of America (VOA) Indonesia on May 24, 2017. The rejection from the Amnesty International Director for Southeast Asia and the Pacific, Josef Benedict has condemned the punishment and called it as the violation of international human rights law. The global society is encouraged to emphasize Indonesia in order to create a safer environment for the LGBT society before the situation worsens, and it is stated that no one should be punished for a relationship of love (Mazrieva, 2017).

Based on preliminary studies conducted by researcher, it is obtained some information presented in the interview excerpt as follows:

"For me, the punishment of judicial caning will have a learning effect for many parties, not only violators but also others so as to prevent violations of Islamic Sharia"

(Personal Interview), 11/15/2016, $\mathrm{R} / 35$ Years). 
"In my opinion the good and bad shortterm deterrent effect, but, if the long term will cause revenge. Generally, the form is remorse but an effect on the environment could be that he is very isolated and not confident. " (Personal interview, 14/11/11, G/23 Years).

The pro and con are shown by those who support and those who lead to the rejection of the implementation of judicial caning as a form of the implementation of the Law of Qanum Jinayat in Aceh (Dinas Syariat Islam Aceh, 2015). The pro and con are stronger after the enactment of Aceh's Governor Regulation (Pergub) No. 5 of 2018 concerning the implementation of the jinayat procedural law and contains the rules for implementing judicial caning in the Penitentiary.

The implementation of judicial caning is expected to reduce violations of the Islamic Shari'a in Aceh, but the implementation of judicial caning has caused different society reactions. This is efffected by the individual's acceptance of a stimulus or event, besides this acceptance will further affect the perception or assessment of individuals and society. Perception is the process of receiving stimuli (objects, qualities, relationships between symptoms, and events) which are then realized and understood (Irwanto, 2002).

The diverse perceptions from the society can be formed from knowledge and expectation, and can be strengthened by affection reactions (Blake, 2006). This can be seen from the following interview:

"Yesterday, when I saw the implementation in front of the crowd, I was a little disappointed because there was a reading of the curriculum vitae, to the origin and name of the parents, for the process, I agreed, but for the systematic implementation, it needed to be improved." (15 / 10/2018, M / 20 Years).

The diverse view and perception of the society regarding judicial caning can be caused by many parties do not yet properly understanding about the nature of jinayah law, the purpose of punishment, and order as well as the Shari'a that they want to realize by enforcing jinayah law. In addition, there is a lack of knowledge and information about the process of implementing judicial caning. The urgency of this study is to find out the society's views on judicial caning which can then formulate recommendation to stakeholders regarding the implementation of judicial caning and reveal the phenomenon of local wisdom in Aceh.

\section{LITERATURE REVIEW}

\section{Perception}

According to Goldstein (2013), perception is the process of observer in applying its knowledge to draw conclusions about whether the object through all that is seen, heard, felt, smelled made by the mechanism of sense organs. Perception as a series of processes that begin with environmental stimulus and end with perception, recognition, and action, the whole process is dynamic and constantly changing.

According to Goldstein (2013) there are a series of processes that occur before individuals produce interpretations and react to what is captured by the senses. The process consists of three main components, namely: 
a. Stimulus: stimulus is what is in the environment, what attracts individual attention and what stimulates receptors (cells that are sensitive to stimuli). Everything that is in the environment and has the potential to attract the attention of individuals and it is mentioned as the environmental stimulus and when one of the stimulus is the focus of individual attention, the stimulus is called as attended stimulus.

b. Physiological Process: the stimulus that becomes the focus of attention and then transformed and transmitted to the brain. One of the basic principles of perception is everything that an individual perceives is based on signals in the nervous system.

c. Behavioral Response: individual perceives a stimulus that is the object of perception after being processed in the brain. What is perceived by individuals determines individual reactions and actions to perceived stimulus. Goldstein (2013) states that perception is influenced by knowledge factors.

Goldstein further explains that knowledge in the context of perception are matters that are known by individuals in connection with stimuli and it affects on the perceptual situations. Perception is a process that involves psychological and physiological processes, therefore, it is necessary to know on how knowledge, memories, and expectations of individuals related to the situation perceived.

\section{Caning}

Aceh is the only province in the Unitary State of the Republic of Indonesia (NKRI) which, under the special autonomy law, has full authority to implement the Islamic Sharia with the establishment of a number of regional regulations for the province known as Qanun (Fikar \& Mutiarin, 2014). Judicial caning is one type of punishment contained in Qanun Aceh Number 6 of 2014 concerning Jinayah Law. Judicial caning referred to in the Jinayah Qanun is a bat with a diameter of $0.75 \mathrm{~cm}$ to 1 (one) centimeter, length of 1 (one) meter and it does not have double or split ends (Zainuddin, 2011). Whereas the judicial caning in Arabic is called jald derived from the word jalada (hitting on the skin or hitting with a whip made of leather) (Jabbar \& Hanum, 2018).

\section{The Perception of Society on Judicial Caning}

Perceptions that arise from the society towards the implementation of judicial caning are classified into two parts, namely positive, it means that the agreement on the implementation of judicial caning and negative perceptions that only see from the bad side of judicial caning (Abubakar, 2012).

The implementation of Shari'a is seen as having the potential to protect the society of Aceh and facilitate its integration into Indonesia's national culture, including te particularly on the experience of the rise of Islam (Feener, 2013).

Sanctions in the form of punishment for learning and making people deterrent from repeating their actions. The different perceptions of the implementation of judicial caning are certainly based on perceptual factors that affect each individual.

Judicial caning in Aceh is carried out in the open, witnessed and exhibited to the general public (Ablisar, 2014). The 
execution of judicial caning certainly provides many distinctive views from the public, both those who carry out judicial caning, those subject to punishment, and the audience. Judicial caning carried out in accordance with Islamic Sharia is expected to give a deterrent effect to the society and only provide temporary physical pain, it does not cause permanent injury, especially on open body parts (Surbakti, 2010). The society perception of judicial caning is determined by understanding and knowledge of society in which it is influenced by social and cultural backgrounds that are formed through the socialization process of values and norms that develop (Ananda, 2016). The society wants the implementation of Islamic Sharia and the implementation of judicial caning to continue in Aceh in the future. However, some people are still unfamiliar with the implementation of judicial caning (Sumiadi \& Faisal, 2008).

\section{RESEARCH METHOD}

This study used a qualitativephenomenological method with a Psychophysical approach that explained about how the relationship of stimulus and behavioral response and how other factors such as knowledge, memory, and expectations of the situation effect on perception (Goldstein, 2013). The respondent consisted of 31 people from generap public in the 3 areas of Banda Aceh, they were selected with purposive sampling technique. Characteristics of research respondents, namely 1) Men / Women, 2) Ages 20-55 years, 3) Minimum education of high school graduates / equivalent, 4) Working / Not Working, 5) The society in the area of the judicial caning is carried out. This research was conducted in Gampong Rukoh, Gampong Lamgugob and Gampong Lueng Bata. The data collection was conducted by observation and FGD techniques. Data analysis was undertaken using an interactive model that refers to the theories of Miles and Huberman (1994), consisting of the stages of data collection, data reduction, data display, and conclusion or verification.

\section{RESULT}

Knowledge assessment is carried out prior to focus group discussions to measure the level of society knowledge related to judicial caning and the implementation of the Qanun jinayah. The societies from three (3) regions in Banda Aceh City involved as research respondents (a total of 31 people) have a percentage of knowledge that can be seen in Table 1.

\section{Table 1}

Level of Society Knowledge on Judicial

Caning

\begin{tabular}{lc}
\hline \multicolumn{1}{c}{ Regions } & $\begin{array}{c}\text { The Percentage of } \\
\text { Society Knowledge }\end{array}$ \\
\hline Gampong Lamgugob & $57 \%$ \\
Gampong Rukoh & $41 \%$ \\
Gampong Lueng Bata & $26 \%$ \\
\hline Mean & $\mathbf{4 1 \%}$ \\
\hline Based on the & knowledge
\end{tabular}

assessment from the three groups of respondents, it indicates that the average level of society knowledge of the three regions is $41 \%$. These results point out that the public does not yet have sufficient knowledge and comprehensive understanding regarding the implementation of judicial caning and Qanun Jinayah. 
Table 2

Comparison between respondents

\begin{tabular}{|c|c|c|c|}
\hline $\begin{array}{c}\text { The Component of } \\
\text { Perception }\end{array}$ & $\begin{array}{l}\text { Respondent } \\
\text { Group I (LB) }\end{array}$ & $\begin{array}{c}\text { Respondent } \\
\text { Group II (LG) }\end{array}$ & $\begin{array}{l}\text { Respondent } \\
\text { Group III (RK) }\end{array}$ \\
\hline \multirow[t]{3}{*}{ Stimulus } & $\begin{array}{l}\text { Never witness directly } \\
\text { the process of judicial } \\
\text { caning }\end{array}$ & $\begin{array}{l}\text { Witness judicial caning } \\
\text { more than once }\end{array}$ & $\begin{array}{l}\text { Witness judicial caning } \\
\text { directly }\end{array}$ \\
\hline & $\begin{array}{l}\text { The lack of an } \\
\text { information about the } \\
\text { judicial caning. The } \\
\text { information gained is } \\
\text { merely from mass media }\end{array}$ & $\begin{array}{l}\text { Know about the judicial } \\
\text { caning because they have } \\
\text { ever watched directly }\end{array}$ & $\begin{array}{l}\text { Gain an information about } \\
\text { judicial caning directly }\end{array}$ \\
\hline & The lack of socialization & $\begin{array}{l}\text { Obtain the socialization } \\
\text { from the government }\end{array}$ & \\
\hline \multirow[t]{6}{*}{$\begin{array}{l}\text { Behavioral } \\
\text { Response }\end{array}$} & $\begin{array}{l}\text { Discover about one type } \\
\text { of violation of Islamic } \\
\text { Sharia that can be } \\
\text { imposed to judicial } \\
\text { caning }\end{array}$ & $\begin{array}{l}\text { Discover about the } \\
\text { implementation of judicial } \\
\text { caning and some types of } \\
\text { violations of Islamic } \\
\text { sharia which can be } \\
\text { imposed to judicial caning }\end{array}$ & $\begin{array}{l}\text { Discover about the judicial } \\
\text { caning that imposed on } \\
\text { perpetrators of adultery } \\
\text { and khalwat }\end{array}$ \\
\hline & $\begin{array}{l}\text { Feel a scare and sad so } \\
\text { that they do not witness } \\
\text { the judicial caning. }\end{array}$ & $\begin{array}{l}\text { Feel sad and pity during } \\
\text { watching the judicial } \\
\text { caning. }\end{array}$ & $\begin{array}{l}\text { The society is involved in } \\
\text { preventing violations of the } \\
\text { Islamic Sharia by the Team } \\
\text { Tamar.. }\end{array}$ \\
\hline & $\begin{array}{l}\text { The implementation of } \\
\text { judicial caning has not } \\
\text { been effective enough } \\
\text { because of several } \\
\text { shortcomings in its } \\
\text { implementation }\end{array}$ & $\begin{array}{l}\text { Feel the execution } \\
\text { procedure is not optimal. } \\
\text { The lack of seriousness of } \\
\text { the executor in } \\
\text { implementing the judicial } \\
\text { caning policy }\end{array}$ & $\begin{array}{l}\text { Not effective enough } \\
\text { because it is not in } \\
\text { accordance with religious } \\
\text { guidance and there are still } \\
\text { many shortcomings in the } \\
\text { implementation process. }\end{array}$ \\
\hline & $\begin{array}{l}\text { Judicial caning received } \\
\text { by violators of Islamic } \\
\text { Sharia is not equal with } \\
\text { the mistakes that the } \\
\text { violators have carried } \\
\text { out }\end{array}$ & $\begin{array}{l}\text { The punishment given to } \\
\text { the convicted person has } \\
\text { not been equal because it } \\
\text { is not in accordance with } \\
\text { Islamic provision }\end{array}$ & $\begin{array}{l}\text { The punishment given to } \\
\text { the convicted person has } \\
\text { not been worth it }\end{array}$ \\
\hline & $\begin{array}{l}\text { The benefits of judicial } \\
\text { caning is as a learning }\end{array}$ & $\begin{array}{l}\text { Judicial caning is a lesson } \\
\text { for others. Judicial caning } \\
\text { has a better impact than } \\
\text { imprisonment }\end{array}$ & $\begin{array}{l}\text { Judicial caning provides } \\
\text { education and learning as } \\
\text { well as benefits to other } \\
\text { societies in order to not } \\
\text { violate the Islamic Sharia } \\
\text { and not to embarrass the } \\
\text { convicted }\end{array}$ \\
\hline & & $\begin{array}{l}\text { Justice needs to be applied } \\
\text { in the presence of } \\
\text { evidence and thorough } \\
\text { investigation before the } \\
\text { execution of the } \\
\text { punishment }\end{array}$ & $\begin{array}{l}\text { It is necessary to apply } \\
\text { justice and the } \\
\text { implementation of } \\
\text { punishment to all people }\end{array}$ \\
\hline
\end{tabular}


The following results of group discussions with society from three regions in Banda Aceh, namely:

1. The process of judicial caning is very influential in the development of children who witness the execution of judicial caning directly.

2. The clear rules must be enforced in the process of judicial caning.

3. The deterrent effect and learning for violators and others.

4. The convicted of judicial caning needs a psychological rehabilitation.

5. Socialization from the party of the Islamic Sharia implementation is still lacking so that it causes a lack of society knowledge related to the provisions and the system of implementing on judicial caning. Knowledge is limited to general information such as certain types of violations of Islamic law.

6. The tendency of injustice and consistency in the enforcement of Islamic Law. It is expected to not record and spread the process of execution of judicial caning to social media.

8. It is essential for having earlier education from family that can prevent violations of Islamic Sharia.

9. Control function with the TAMAR Team as a supervisor and prevent violations of Islamic Law.

10. Some people avoid watching the judicial caning execution due to feel a pity and compassion.

The results obtained are then categorized into several themes / aspects and analyzed from psychological reviews, as in Table 3.
Table 3

Themes of Research Results (Psychological Review)

\begin{tabular}{ll} 
Element & \multicolumn{1}{c}{ Research Themes } \\
\hline Cognitive & $\begin{array}{l}\text { Knowledge and understanding } \\
\text { about Judicial caning and Qanun } \\
\text { Jinayah } \\
\text { Justice and consistency in } \\
\text { enforcement of the punishment } \\
\text { The importance of psychological } \\
\text { rehabilitation for convicts who are } \\
\text { imposed to judicial caning } \\
\text { The impact of the judicial caning } \\
\text { process is witnessed directly by } \\
\text { children } \\
\text { Society reactions and responses } \\
\text { Feel compassion for the convict } \\
\text { who is imposed to judicial caning } \\
\text { The role of the society in } \\
\text { preventing violations of Islamic } \\
\text { Sharia } \\
\text { The function of the environment } \\
\text { control is to prevent violations of } \\
\text { Islamic Law }\end{array}$ \\
\hline
\end{tabular}

\section{DISCUSSION}

The implementation of judicial caning effects on the dynamics of society's behavior in Aceh. The lack of society support for the implementation of Islamic Sharia as a whole in all aspects of life becomes a challenge (Muzakkir, Thaib, Suhaidi, \& Abdullah, 2017). Various society perceptions of judicial caning are effected by society's knowledge and understanding of the enforcement of Islamic Sharia with the implementation of judicial caning as the form of applying Qanun Jinayat. Knowledge is a learning process and a reinforcing factor that effects on individual behavior that can be sourced from family, society and mass media (Myers, 2012). This is in line with information obtained from research respondents that socialization regarding the implementation of Islamic Sharia 
needs to be continuously carried out with various alternative media, both directly and through other media.

The implementation of Islamic law requires the role of all parties. Ulya (2016) argues that the government is responsible for providing understanding to the society. The family and the environment also have an important role in the process of delivering information related to the implementation of Islamic Sharia, especially about the judicial caning for violators of the Qanun Jinayah. The family is the beginning of Islamic Sharia education so that children have an early awareness that individuals have rules of life (Sutrisno, 2016).

Muhammadin, Wicaksono, Sari, and Ayutama (2019) argues that the judicial caning is a persecution is incorrect. Danial (2012) states that the deterrent effect can provide a decrease in the number of violators of Islamic Sharia because the convict is regret for its actions and feels ashamed of being publicly punished). In addition, the purpose of judicial caning is carried out openly in the presence of the society in order to prevent similar acts and as learning for the whole societies (Safinah, 2016). Judicial caning can affect the psychological condition of the convicted person. This is a challenge issue in the implementation of Sharia by the government in Aceh (Taylor, 2015). The process of returning to family and society is also not yet integrated enough so that convicts who violate the Shari'a may feel excluded from their environment and cannot return to be a normal life. The process of recovery and rehabilitation has not yet been carried out even though this has been stated in the Qanun Jinayah. The psychological condition when the violator returns to the community, it needs to be considered so that the convicted person can be accepted in their environment (Sutrisno, 2016).

\section{CONCLUSION}

The diverse view and perception of the process of judicial caning for violators of Islamic Sharia in Aceh in which it is strongly effected by the people's knowledge and understanding on the Qanun Jinayah. The principle of fairness and consistency in enforcing the rules also affect the society's judgment. The variety of view and perception of judicial caning can affect society's behavior.

The various behaviors that often emerge toward the judicial caning are documenting the process of judicial caning and spreading it through social media; inviting the children to witness the process of judicial caning; shouting/ blaspheming the violator who is punished of judicial caning and various other behaviors.

The mechanism in the process of execution of judicial caning is important to minimize the psychological impact, especially for children. The deterrent effect and shame provide learning process to individuals and other societies in order to not violate Islamic Sharia. Society care and strengthening community capacity, and the support and the role of the family as the pioneer can prevent violation of Islamic Sharia.

Some suggestions from the results of this study are: 1) For further researchers can conduct further research by adding respondents from the society who have been convicted of judicial caning and expanding the research area. 2) Recommendation to the government 
namely to carry out continuous socialization of the implementation of Islamic Sharia on the society. The preparation of psycho-education modules to the society related to preventive programs, so as to minimize the number of violations of Islamic Sharia.

Strengthening the capacity of families and societies as a function of social control. The need to enforce the rules when the execution of judicial caning in anticipating the involvement of children. In addition, there is a need for psychological rehabilitation mechanisms for the convicted of judicial caning before and after judicial caning. 


\section{REFERENCES}

Abbas, S. (2011). Dimensi pemikiran hukum dalam implementasi Syariat Islam di Aceh. Aceh: Dinas Syariat Islam Aceh.

Ablisar, M. (2014). Relevansi hukuman cambuk sebagai salah satu bentuk pemidanaan dalam pembaharuan hukum pidana. Jurnal Dinamika Hukum, 14 (2), 278-289.

Abubakar, A. (2012). Kontroversi hukuman cambuk. Media Syari'ah, 14 (1), 65-95.

Ananda, R. R. (2016). Persepsi masyarakat terhadap pelaksanaan hukum cambuk di Kota Banda Aceh. Skripsi (tidak diterbitkan). Fakultas FISIPOL Universitas Syiah Kuala.

Blake, R., \& Sekuler, R. (2006). Perception. New York: McGraw Hill.

Danial. (2012). Qanun Jinayah Aceh dan perlindungan HAM (kajian yuridisfilosofis). Jurnal Kajian Hukum Islam, $6(1), 85-98$.

Dinas Syari'at Islam Aceh. (2015). Hukum jinayah dan hukum acara jinayah. Banda Aceh: Naskah Aceh.

Feener, F. M. (2013). Social engineering through shari'a: Islamic law and state-directed da'wa in contemporary Aceh. Indonesia Law Review, 3 (3), 285-310.

Fikar, M., \& Mutiarin, D. (2014). Tata kelola kebijakan Qanun Nomor 13 Tahun 2003 Tentang Maisir (Perjudian) di kabupaten Gayo Lues provinsi Aceh. Jurnal Ilmu Pemerintahan dan Kebijakan Publik, 1 (3), 548-572.

Goldstein, E. B. (2013). Sensation and perception (9th ed.). USA: Wadsworth Cengage Learning.
Institute for Criminal Justice Reform. (2017). Hukuman cambuk mencoreng wajah hak asasi manusia di Indonesia. Retrieved April 28, 2018, from http://icjr.or.id/hukuman-cambukmencoreng-wajah-hak-asasimanusia-di-indonesia/.

Irwanto. (2002). Psikologi umum (buku panduan mahasiswa). Jakarta: PT. Prehallindo.

Jabbar \& Hanum, Z. (2018). Pengawasan pelaksanaan uqubah cambuk. Legitimasi, 7 (2), 265-283.

Mahdi. (2011). Sistem hukum penegakan Qanun Jinayah di Aceh. Media Syariah, 13 (2), 179-192.

Mazrieva, E. (2017). Kontroversi hukuman cambuk di Aceh. VOA Indonesia. Retrieved April 28, 2018, from https://www.voaindonesia.com/a/ac eh-hukum-cambuk-pasangan-gay/3867986.html.

Miles, M. B., \& Huberman, A. M. (1994). Qualitative data analysis: An expanded sourcebook (2nd ed.). Thousand Oaks, CA: Sage Publications.

Muhammadin, F. M., Wicaksono, D. A., Sari, A. C. F., \& Ayutama, O. A. (2019). Lashing in qanun Aceh and the convention against torture: A critical appraisal. Jurnal Media Syariah, 7 (1), 11-24.

Muzakkir, Thaib, H., Suhaidi, \& Abdullah, Z. (2017). Implementation of law in Aceh after application Qanun Jinayah. International Journal of Humanities and Social Science Invention, 6 (9), 1-7.

Myers, D. G. (2012). Social psychology. (Aliya Tusyani, Trans). Jakarta: Salemba Humanika.

Pemerintahan Aceh. (2014). Indeks Hukum Qanun. Retrieved April 28, 2018, 
from

https://www.acehprov.go.id/hukum /category/2.html.

Peraturan Gubernur Aceh Nomor 5 Tahun 2018 Tentang Pelaksanaan Hukum Acara Jinayat.

Qanun Aceh Nomor 6 Tahun 2014 Tentang Hukum Jinayat. Dinas Syariat Islam Aceh. Retrieved April 28, 2018, from

https://dsi.acehprov.go.id/wpcontent/uploads/2017/02/QanunAceh-Nomor-6-Tahun-2014Tentang-Hukum-Jinayat.pdf.

Safinah. (2016). Sanksi hukum terhadap perbuatan liwath dengan anak di bawah umur. Jurnal Petita, 2 (2): 192213.

Sumiadi \& Faisal. (2008). Persepsi masyarakat terhadap pemberlakuan hukum cambuk di wilayah Kota Lhokseumawe dalam rangka penerapan Syariat Islam yang kaffah di Nanggroe Aceh Darussalam. Jurnal Suloh, 6 (2), 97-174.

Surbakti, N. (2010). Pidana cambuk dalam perpektif keadilan hukum dan hak asasi manusia di Provinsi Nanggroe Aceh Darussalam. Jurnal Hukum, 3 (7), 456-474.

Sutrisno, I. H. (2016). Case study roles of Islamic law in the perspective of sociological the community Langsa. Journal of Research in Humanities and Social Science, 4 (9), 69-78.

Taylor, R. (2015). Syariah as heterotopia: Responses from muslim women in Aceh, Indonesia. Religions, 6 (2), 566593.

Ulya, Z. (2016). Dinamika penerapan hukum jinayah sebagai wujud rekonstruksi Syari'at Islam di Aceh. Jurnal Rechtsvinding, 5 (1), 135-148.
Zainuddin, M. (2011). Problematika hukuman cambuk di Aceh. Banda Aceh: Dinas Syariat Islam Aceh. 